\title{
SLAVE BUT NOT CITIZEN: FREE PEOPLE OF COLOR AND BLOOD PURITY IN COLONIAL SPANISH AMERICAN LEGISLATION
}

\section{ESCLAVO PERO NO CIUDADANO: LIBRES \\ DE COLOR Y PUREZA DE SANGRE EN LA LEGISLACION COLONIAL EN LA AMERICA HISPANA}

\author{
Aline Helg \\ Université de Genève
}

\section{Resumen}

En 1946 el sociólogo Frank Tannenbaum ofreció una imagen positiva de la esclavitud en América Latina. Desde entonces, sus consideraciones respecto a la esclavitud han sido replanteadas. Sin embargo, se ha prestado poca atención a su afirmación de que una vez emancipados, los antiguos esclavos se convirtieron en ciudadanos. En este artículo analizamos la posición de la gente libre de color en la legislación colonial en la América hispana que les discriminaba y les impedía la posibilidad de ocupar un cargo en las instituciones civiles, militares y eclesiásticas mediante el requisito legal de la pureza de sangre. Este tipo de exclusiones raciales fueron suprimidas en los inicios del proceso de independencia de la América hispana continental pero se mantuvieron vigentes en Cuba y en Puerto Rico hasta la década de 1880.

Palabras clave: Esclavitud, pureza de sangre, ciudadanía, América Latina.

\begin{abstract}
In 1946, sociologist Frank Tannenbaum offered a positive image of Latin America's slave. Since then, his views on slavery have been revised, but little attention has been paid to his claim that once freed, former slaves became citizens. This article focuses on the position of free people of color in colonial Spanish American law, which discriminated against them and barred them from civil, military and church positions through the legal requirement of blood purity. Such racial exclusions were lifted at the onset of continental Spanish America's independence process, but were in force in Cuba and Puerto Rico until the 1880s.
\end{abstract}

Keywords: Slavery, blood purity, citizenship, Latin America. 
In 1946, U.S. sociologist and professor of Latin American history Frank Tannenbaum published his seminal work, Slave and Citizen; the Negro in the Americas. ${ }^{1}$ Inspired by his Brazilian colleague Gilberto Freyre, whose lectures at Indiana University had just been issued under the title Brazil, an Interpretation, ${ }^{2}$ Tannenbaum was intrigued by "the divergent position of the Negro" in the United States and Brazil toward the end of World War II. ${ }^{3}$ To explain these differences, he broadly compared slavery in "Anglo-Saxon" (U.S. and British) America with slavery in Latin America, focusing mostly on legislation and the role of the church. He pointed to what he saw as the crucial difference: in Latin America "The Negro... had acquired a moral personality while slavery still flourished". Once baptized, he was equal to his master in the eyes of God; he was protected by the law against abuse and could buy his freedom and that of his loved ones. "He remained a person even while he was a slave. He lost his freedom, but he retained his right to become free again", thanks to laws and Catholicism that supported manumission. ${ }^{4}$ Moreover, in Latin America "slavery itself carried no taint"; "once free, the Negro enjoyed, on the whole, a legal status equal to that of any other subject of the King or to that of any other citizen of the state. And if the question of color was an issue, he could purchase 'whiteness' for a specific price". ${ }^{5}$ In contrast, Tannenbaum continued, in Anglo-Saxon America, the

1 TANNENBAUM, F. (1946): Slave and Citizen; the Negro in the Americas. Alfred A. Knopf, New York.

2 FREYRE, G. (1945): Brazil, an Interpretation, New York, Alfred A. Knopf.

3 TANNENBAUM: Slave and Citizen, p. 4.

4 TANNENBAUM: Slave and Citizen, pp. 93 and 98.

5 TANNENBAUM: Slave and Citizen, pp. 89 and 93. 
legislation considered slaves as chattel without legal protection or moral personality, thus as essentially incapable of freedom and citizenship. Tannenbaum's ground-breaking comparison has generated extensive debate since more than half a century, and the intent of my article is not to add new layers to old issues. Its purpose is to highlight an important omission in Tannenbaum's argument on the transition from slavery to freedom in colonial Spanish America: the requirement of limpieza (or pureza) de sangre (purity of blood) for most civil, military, and church positions, for admission to higher education, and for all kinds of grants and honors. To be fair, Tannenbaum hinted that "color" could be an issue, as shown in the above quotation, but he dismissed it by immediately (and incorrectly) adding that then "whiteness [could be purchased] for a specific price". Curiously, to my knowledge, no commentator of Slave and Citizen has pointed to this omission despite the fact that it seriously nuances Tannenbaum's assessment. ${ }^{6}$

Equally neglected by commentators is the fact that Slave and Citizen did not examine the citizen and citizenship per se or comparatively. The book mentioned the word twice: first, in the already cited sentence referring to Latin America: "once free, the Negro enjoyed, on the whole, a legal status equal to that of any other subject of the King or to that of any other citizen of the state"; and second, when it explained the basic difference in the position of the freedman after manumission: in Latin America " $[t]$ he freedman was a free man". In the United States, "the Negro was the slave, and the white man was the free man...for all the things denied to the Negro as a slave were permitted to the white man - as a citizen". In fact, Tannenbaum explored mostly slavery and manumission, but to him "citizen" is rather an extension of the word freedman, which he used in the book's title to make an interesting contrast with "slave". More intriguing is his neglect of the racially discriminating impact of limpieza de sangre on freedmen and freeborn in colonial Spanish America (rather than in Brazil). Indeed, contrary to Tannenbaum's claim that "slavery itself carried no taint", by law it left the indelible mancha de la esclavitud (stain of slavery) on the manumitted and their offspring and significantly restricted the rights and freedoms of people of African descent as compared to those of whites.

For some recent comments ignoring limpieza de sangre, see DE LA FUENTE, A. \& GROSS, A (2010): "Comparative Studies of Law, Slavery, and Race in the Americas". Annual Review of Law and Social Science, vol. 6:1, pp. 469-485; and KEMNER, J. (2012): "¿Eran ciudadanos los afrodescendientes libres en las sociedades esclavistas? Cuba, Brasil y Estados Unidos en el siglo XIX". Procesos: Revista Ecuatoriana de Historia, vol. 26, pp. 9-38. 
This article begins with a brief presentation of slavery and the legal statuses of blood purity in the lberian Peninsula, before turning to their transfer to America after 1492. Next, on the basis of royal legislation and judicial cases, it examines their evolution during the late eighteenth-century Bourbon reforms and the Haitian Revolution. Then it focuses on the Spanish empire's 1812 first monarchical constitution and its impact on free people of color and on independence. It ends with a brief examination of slavery and the requirements of blood purity in Cuba and Puerto Rico, which remained Spain's last American colonies until 1898.

\section{Peninsular origins and American translations}

Fourteen hundred ninety-two was not only the year Christopher Columbus landed in Hispaniola. It was also the year Granada, Muslims' last stronghold in Spain, fell, and the year the Jews were expelled from the Iberian Peninsula. Since the eighth century, Spain and Portugal had been under Muslim rule, and since the year 1000, Spanish Christians had slowly re-conquered the Peninsula. In that process, they developed several institutions and laws that they would transfer to America, among them, slavery and limpieza de sangre.

As thoroughly described by Tannenbaum, slavery was well established in Spain prior to 1492. It had prevailed in the Mediterranean world centuries before Christianity, and was linked to war: men, women and children taken in just wars could be enslaved. Slavery had been an institution in Muslim Spain and continued undisputed in Catholic Spain. According to the Roman-derived laws of Las Siete Partidas (seven parts) issued in 12561265, slaves were, simultaneously, human beings created by God who could marry and try to gain their freedom through manumission, and things or human property that could be bought, sold, hired, confiscated, and inherited. In the sixteenth century, 10 to 15 per cent of the inhabitants of Spain's port-cities were slaves, and throughout the Peninsula owning domestic slaves was a sign of high standing and nobility. By 1550, slaves' origins had also evolved from being mostly peninsular Jews and Muslims or North Africans, to being from Sub-Saharan Africa and, thus, black. ${ }^{8}$

Unlike slavery, limpieza de sangre had no origin in the Roman law or Muslim Spain, but emerged with the end of the Reconquista. In 1492, one of the purposes of the Catholic Kings Isabel I of Castile and Ferdinand II of Aragon was to extirpate the Muslim and Jewish heritages within the population, which they did by promulgating discriminatory and segrega-

8 STELLA, A. (2000) : Histoires d'esclaves dans la péninsule ibérique.EHESS, Paris. 
tion laws, or estatutos de limpieza de sangre (statutes of blood purity). At the beginning, the monarchy targeted Muslims and Jews only for their religious practices and forced them to convert to Catholicism, but this rapidly led to the accusation that converts secretly continued to worship their original religion. As a result, in 1481 the Inquisition was established to investigate false conversions and heresy. In the following two decades, all non-converted Jews (1492) and Muslims (1502) were expelled from the Peninsula. By the mid sixteenth century, in order to apply to most royal and ecclesiastical positions, it was necessary to demonstrate not a single Jewish or Muslim ancestor in one's genealogy as well as numerous documents proving generations of Catholic baptism and marriage. Furthermore, it was believed that the unfaithfulness of Jews and Muslims had endured in those who had converted to Catholicism (conversos), and then had been passed on by blood to their descendants, even if the latter were sincere Christians. In 1609, King Philip II ordered the expulsion of all Muslim and Jewish conversos from Spain. However, whereas non-converted Muslims and Jews could be identified by their dress and customs, by definition conversos resembled Catholics. In the absence of visible markers, the Inquisition turned to genealogy or "blood" to detect them. Any Jewish or Muslim ancestry in one's genealogy became a proof of dubious Christianity, converso status, and blood impurity. In practice, certificates of blood purity attesting three generations of Catholicism for one's mother and father, backed by "pure" Christians' letters of recommendation, became compulsory to join brotherhoods and corporations, to apply to civil, military, and church positions, to the university, to non-manual professions, and to all grants and honors. Other inherited requirements were added, such as legitimate birth and non manual-degrading work. This obsession with lineage ended up racializing religion, or rather, religious exclusion became racial as it was equated not with faith but with Jewish or Muslim ancestry. Religious exclusion also became social, because it disqualified for limpieza de sangre the new Christian commoners of dubious origins who were small traders, artisans, peasants, or day laborers; but it qualified all hidalgos, the lower "nobles" without land or wealth, whose forebears gained their privileges by fighting in the Reconquista against the Moors. At the outset, anyone without a Jewish or Muslim ancestor could qualify for blood purity, but through the added requirements mentioned above, the hidalgos and the higher nobility ended up embodying blood purity.

9 SICROFF, A.A. (1960) : Les controverses des statuts de 'pureté de sang' en Espagne du 15e au 17e siècle, Didier, Paris; NIRENBERG, D. (2009): "Was There Race before Modernity? The Example of 'Jewish' Blood in Late Medieval Spain", in ISAAC, B., ZIEGLER, Y. \& ELIAV-FEL- 
After 1492, Spanish laws and institutions were transported to America and adapted to their new environment. Slavery was at first the destiny of the Amerindians, but their demographic decline, due to disease and abuse, was so rapid that, by 1570, Indian slavery was outlawed. After much debate (involving Bartolomé de las Casas), it was decided that the Conquest of America was not identical to a just war. It was God-engineered chance for the Native Americans, who had not been contaminated by Islam, Judaism or heresy, to become Christian. Thus, Indians could not be legally enslaved anymore, but as Spaniards still needed their labor, they relocated them in segregated pueblos de indios (villages for Indians) supervised by Catholic priests and headed by Indian caciques in charge of collecting the tributo de indios (indigenous head tax) and providing quotas of workers for the mines, workshops, and agriculture. ${ }^{10}$

Simultaneously, blacks ended up being the only legal slaves, because they were implicitly captured in just wars against Muslims in Africa. The first black and mulatto captives came from Spain with the conquistadores. But rapidly they were outnumbered by slaves directly imported from West Africa to work in the mines and the homes of Spaniards in Mexico, Peru, and wherever the colonizers settled. As most of the territory remained unconquered, many slaves managed to run away and squat in the hinterland, to form maroon communities or to mix with displaced indigenous people. With Las Siete Partidas and its regulations on manumission implemented in Spanish America, slaves also endeavored to buy their freedom. As a result, with comparatively few Spaniards migrating to America, freedmen of full or mixed African origin (some of them unclaimed runaway slaves) formed a growing part of the free population, notably in the cities and the coastal regions.

Together with slavery, the requirements of limpieza de sangre transferred and adapted to America, as the Inquisition established offices in Mexico and Lima in 1569, and in Cartagena de Indias in 1610. Only Catholic Spaniards were allowed to settle in the "new" continent, and, replicating the process of the Reconquista, there conquistadores and early colons shared the same privileges of blood purity as Spain's hidalgos -as

DON, M. (eds.): The Origins of Racism in the West. Cambridge UP, Cambridge, pp. 232-264; CARRASCO, R., MOLINIÉ, A. \& PEREZ, B. (dirs.) (2011): La pureté de sang en Espagne: du lignage à la «race», Presses Universitaires Paris-Sorbonne, Paris.

10 BÖtTCHER, N., HAUSBERGER, B. \&.HERING TORRES, M.S. (eds.) (2011): El peso de la sangre: Limpios, mestizos y nobles en el mundo hispánico. El Colegio de México, México. 
long as they were of legitimate birth and non-manual workers-. Now that by royal decree American Indians could not have been contaminated by impious faiths before their evangelization and could not be enslaved anymore, the Spanish monarchy recognized Indians' lineages of nobility and declared them eligible for blood purity, as were the Spaniards. Therefore, children of mixed indigenous-Spanish ancestry could also claim blood purity if they could prove three generations of Catholic baptism, legitimate birth and non-manual labor. At the same time, the prohibition for Jews, Muslims, conversos or Protestant to migrate to Spanish America led to few actually settling in the continent. As a result, the source of blood contamination was increasingly located in the African ancestry, which combined the stigma of possible Muslim origins (religion) and slavery (status). Concretely, the ideology of blood purity began to focus less on religious heritage, as it did in Spain, and more on inherited physiological differences -the "racial" African origin, such as hair, skin color, facial features-. Lineage was as crucial as in Spain, and genealogical investigations were also requested for all honors, grants, non-manual professions, and royal or church functions as well as in interfamily disputes or contested marriage engagements. Of course, "black blood" (sic) and the "stain of slavery" were two among several "defects" that were traced in family histories; also under examination in one's ancestors were nobility, Spanish origin, conformity with Catholic dogma and practices, professional distinction, and honor, among others. These investigations, documented by numerous certificates and witness depositions, were then archived in special fondos de genealogía. Yet, in America, with Spaniards and their offspring often refusing to perform manual professions, most manual workers, artisans, midwives, phlebotomists, and caretakers, among others, were blacks, mulattos and zambos lof mixed African and indigenous descent). In addition, for social and cultural reasons, they often formed common-law marriages. Therefore, exclusion on the basis of full or partial African ancestry tended to match other exclusions from blood purity, such as manual labor and illegitimate birth. ${ }^{11}$

To sum up, in America, unlike in Spain, race became the primary factor in establishing a free person's limpieza de sangre. Spaniards and Indians and their unmixed or mixed offspring were eligible for blood purity, but

11 MARTíNEZ, M.E. (2008): Genealogical Fictions. Limpieza de sangre, Religion, and Gender in Colonial Mexico. Stanford UP, Stanford. On petitions for marriage among "unequal" partners, see MCKINLEY, M.A. (2010): "Such Unsightly Unions Could Never Result in Holy Matrimony: Mixed-Status Marriages in Colonial Seventeenth-Century Lima". Yale Journal of Law \& the Humanities, vol. 22:2, pp. 217-254. 
"full" blacks and persons with partial African ancestry, either free or enslaved, were excluded. As Spaniards, Indians and Africans mixed -often as the result of rape by Spanish men- a new hierarchy emerged to classify individuals, with the fluid category of the castas (racially-mixed) encompassing anyone with partial or full African and/or indigenous ancestry. The many possible mixtures of European, Amerindian, and African ancestry formed a complex terminology illustrated in the eighteenth-century casta paintings, but in official documents and common language, the basic categories usually were español, blanco, indio, mestizo, castizo, negro or moreno, mulato or pardo, cuarterón, and zambo or coyotes. ${ }^{12}$

The racial paradigm on which colonial society was founded credited whites, Indians, and their mestizo offspring with limpieza de sangre, but attributed a permanent "depraved origin" to African slaves and their mixed or unmixed descendants, even when they were free. African ancestry became a legal marker of exclusion, as blacks were collectively -racially- denied blood purity. People of African descent's genealogies were implicitly rooted in Africa through the transatlantic slave trade -a hereditary stigma called mancha de la esclavitud-. In fact, it was close to the Anglo-Saxon "one-drop of black blood" rule used to differentiate blacks from whites. Moreover, people of African descent's status was assumed to be that of slaves, unless it was specified that they were free, as exemplified by the invention of the category of libres de color for free persons of African descent. Never used to define a white, a mestizo or an Indian, libre preceded de color to show the contradiction between African ancestry and freedom. In brief, slavery and blood impurity were conflated and racialized to target Africans and people of full or partial African descent, enslaved, manumitted, or free-born.

Another area in which race mattered in America was in the imposition of the colonial tributes. As for limpieza de sangre, the tribute was a Spanish institution that was adapted to America. In Spain, all common people paid a tribute called pecho (chest) that marked their condition as plebeians and vassals, in contrast with nobles, clergymen and other privileged individuals or corporations exempted from the tribute, such as the army. After the conquest, in America the tribute embodied the domination of the Spanish

12 MARTÍNEZ: Genealogical Fictions. These categories refer to «mixtures» between the three main «races»: white (called blanco or español), Indian, and black (called negro or moreno). They are: mestizo (white-Indian), mulato or pardo (white-black), and zambo, zambaigo, or coyote (black-Indian); castizo (white-mestizo), morisco or cuarterón (white-mulatto). On casta painting, see KATZEW, I. (2004): La pintura de castas: Representaciones raciales en el México del Siglo XVIII. Turner, Madrid. 
monarchy over its new Indian vassals. As already mentioned, Indians were assigned to pueblos de indios and became the major providers of the tribute thorugh the tributo de indios, which combined an individual head tax and collective labor in the mines, workshops, and agriculture. The privileged exempted from the tribute were all the Spaniards, regardless of their condition, who were collectively granted the status of "conquistadores", as well as the collaborating members of the Indian nobility. In addition, the monarchy explored means to extend the tributo de indios or to introduce another tribute among the new socio-racial categories of free persons born from the mestizaje ("racial mixture") of Spaniards, Indians and Africans. In 1572, a royal decree stipulated that free zambos, born from the union of an Indian and a black, had to pay the tributo de indios. Two years later, the monarchy imposed a new tributo de castas to all free persons of full or mixed African descent, but instructed the viceroys to fix its amount according to the economic situation of the libres de color. As a result, several provinces either did not collect the tributo de castas, or did it sporadically. As for the non-contaminated mestizos (of Spanish-Indian ancestry), they were exempted from the tribute. ${ }^{13}$

Taxation was thus another area in which African ancestry was taken into account. Accordingly, in the case of mulattos, subjected to the casta tribute, the tributary condition of the black parent outweighed the exempted status of the white parent; but for mestizos, exempted from the Indian tribute, only the status of the white parent mattered. The difference had its origin in the fact that for the mulattos, one of the parents was hereditarily "contaminated" by the stain of slavery and blood impurity. Nevertheless, as in reality libres de color lived alongside Spanish and creole whites in the same villages or cities (and sometimes in the same block), the tributo de castas was much more difficult to collect than the tributo de indios, which was entrusted to the caciques responsible of the pueblos de indios. ${ }^{14}$

13 For general studies, see GIBSON, C. (1964): The Aztecs under Spanish Rule. A History of the Indians of the Valley of Mexico, 1519-1810. Stanford UP, Stanford; SPALDING, K. (1984): Huarochirí, an Andean Society under Inca and Spanish Rule. Stanford UP, Stanford.

14 MILTON, C. \& VINSON III, B. (2002): "Counting Heads: Race and Non-Native Tribute Policy in Colonial Spanish America". Journal of Colonialism and Colonial History, vol. 3:3. 


\section{The Bourbon Reforms}

The Seven Years' War (1756-1763) had an enormous impact on America, where all European monarchies launched reforms to refill their treasury. Spain launched the Bourbon reforms in the 1760s and attempted to increase the profits of its American empire without shaking the socio-racial order symbolized by the casta system. The plan was to liberalize trade, improve tax collection and strengthen military defense without weakening the allegiance to the king of the small elite of Spaniards and white creoles who would gain new economic opportunities from the end of Spain's monopole of trade. After 1775, with the rapid transformation of the British continental colonies into the independent United States of America, the Spanish Crown was even keener to secure the loyalty of its colonies' elite. However, unlike in British North America, white elite's longing for more autonomy was tempered by demography: everywhere whites were a minority surrounded by majorities of mixed African and/or indigenous descent, and in several port cities they were particularly concerned with the increasing numbers of free mulattos and blacks, a few of whom exhibited material success and high culture. Thus, the monarchy issued several laws aiming at protecting the "honorable" peninsular and creole whites from possible "infiltration" by castas. The Council of the Indies (or royal Spain's supreme legislative, judicial, and executive institution of government for its American and Asian colonies) strengthened the supremacy of limpieza de sangre and legitimate birth in social hierarchy. Simultaneously, it reaffirmed that those who exercised manual professions, whose lineages were not exempt from illegitimate birth and, above all, those who carried "bad blood", the "bad race of blacks" and the stain of slavery in their genealogy remained excluded from all honors and privileges.

Several reforms pursued the goals of preserving elite's "purity". Marriage was regulated by the 1778 Royal Pragmatic, which prohibited the marriage of partners of unequal class and status under the age of 25 who did not have their parents' consent, making legal unions between whites and castas difficult. In line with Spain's exclusion of people of African descent from limpieza de sangre, the Pragmatic applied to all marriages including whites, Indians, mestizos, and castizos, but not to marriages among blacks, mulattos, and coyotes, collectively considered "depraved by nature", unless they were officers in the militia or they distinguished themselves for their excellent reputation and service. ${ }^{15}$ Interestingly enough, the colonial authorities continued to

15 "Consulta del Consejo de Indias sobre las reglas establecidas de la Audiencia de Méjico en cumplimiento de la real pragmática del año de 1778 referente a los matrimonios" (August 
view non racial criteria, such as "bastardy", as crippling as African ancestry. In 1791, for example, they authorized the marriage in Cuba of a white woman of illegitimate birth and a pardo (mulatto) man (contested by the woman's sister), arguing that they already lived together and had children, and that their respective defects (illegitimacy and "bad race") outmatched each other. ${ }^{16}$

More generally, the Council of the Indies restated the obligation to present genealogies and increasingly linked blood purity to the absence of any African origin. Examinations of limpieza de sangre systematically added "the bad race of blacks" to the list of exclusions that had prevailed in Post-Reconquista Spain. The statutes of all Spanish American universities and seminaries, for example, requested that applicants demonstrate that their ancestors were white, "clean of all bad races of Jew, Moor, mulatto or black". ${ }^{17}$

Vast efforts were made to effectively collect the tributo de castas. However, it encountered broad resistance and could only be gathered in provinces where free blacks and mulattos were a small minority. ${ }^{18}$ Indeed, the Crown faced a dilemma: the rapid growth of the free population of African descent and the increasing means of some of them could represent a important source of revenues for the royal treasury; but white creole and peninsu-

1st, 1781), in KONETZKE, R. (ed.) (1962): Colección de documentos para la historia de la formación social de Hispanoamérica, 1493-1810. vol. 3, t. 2 (1780-1807), CSIC, Madrid, p. 477; MARTINEZ-ALIER, V. (1989): Marriage, Class and Colour in Nineteenth-Century Cuba: A Study of Racial Attitudes and Sexual Values in a Slave Society. Cambridge UP, Ann Arbor, p. 11, 1st ed. 1974.

16 "Consulta del Consejo de la Indias sobre la solicitud de Anna Josefa Fernández, vecina del Puerto del Principe, sobre que se la concediese permiso para contraer matrimonio con Pedro de Estrada, pardo libre" (August 12th, 1791), in KONETZKE: Colección de documentos, pp. 695-697.

17 See "Información de cristiandad y limpieza de sangre acreditada a pedimento de don Marcos Quezada, Cartagena" (1785), Archivo Histórico Nacional de Colombia, Bogotá, Sección Colonia, Fondo Genealogías, rollo 5, ff. 692-710; "Cedulario de la Universidad de Caracas" (1721-1820), in ALMARZA, A.R. (2009): La limpieza de sangre en el siglo XVIII venezolano. Centro Nacional de Historia, Caracas, p. 54.

18 "Consulta del Consejo de las Indias sobre los motivos que ha tenido el gobernador e intendente de Nicaragua para no proceder a la exacción del tributo que se impone a los mulatos y negros libres" (September 10th, 1788), in KONETZKE: Colección de documentos, pp. 628-631; HELG, A. (2004): Liberty and Equality in Caribbean Colombia, 1770-1835. The University of North Carolina Press, Chapel Hill, pp. 64 and 103. 
lar minorities worried more and more that free blacks and mulattos would claim new rights on the basis of their economic success. Thus, the Bourbon Reforms did not comprise a revision of the status of the free population of African descent. In most cases, Spain sided with the white elite and refused to weaken the rule of blood purity and legitimate birth. In 1783, for example, a rich quadroon from Guatemala beseeched for him and his descent the "quality... of citizen able to obtain the positions and honors suitable to Spaniards and honorable artisans", despite the fact that "his quality was infected by a few marriages with mulatto women". Such a grant, he argued, would rightly reward the numerous edifices and infrastructure he had built with his fortune for the benefice of the Crown and would encourage the hardworking clase de pardos. The Council of the Indies rejected his request "for the fatal consequences such a grant could produce among the notorious Spaniards and distinguished Americans", but agreed to "concede him a purely personal insignia, such as a higher rank in the Battalion of the pardo militia, or the exemption of a tax or tribute, some money reward, or a medal" from the Royal Academy of Arts and Crafts. ${ }^{19}$ All these rewards marked the exclusion of this rich quadroon from the "quality" reserved to the "pure" white minority and highlighted the limited possibilities of ascension reserved to those "infected" by the "bad race of blacks": crafts or skilled trades and the militia of pardos and morenos.

This case also illustrates Spain's reliance on the free population of African descent for the defense of its American empire. After the British occupation of Havana and Buenos Aires in the 1760s, the monarchy was forced to build up the disciplined militia in the port cities. However, Spanish and white creole able men were few, and many were unwilling to serve; thus the militia had to recruit mostly free men of color. To improve control over them, the army divided them into pardo and moreno battalions. By law, in the presence of white soldiers, militiamen of color had to take off their hats and bow their heads in sign of subordination; and the "stain of slavery" prohibited them from ascending to ranks higher than captain. But the Crown also needed to secure the loyalty of these units through some benefits. Thus, it granted to militiamen of African descent the military fuero, a judicial prerogative allowing officers and enlisted men to present causes before military tribunals rather than before royal or ordinary courts obeying racially biased laws. The fuero also legally exempted the black and mulatto militiamen from paying the casta tribute where it was collected. Nevertheless, although mili-

19 "Consulta del Consejo de las Indias sobre la instancia de Bernardo Ramírez" (September 17th, 1783), in KONETZKE: Colección de documentos, pp. 530-535. 
tiamen of African descent received some privileges from which they gained a higher status in their community, they did so entirely as a reward for their armed service to the king, not because of a revision of the exclusions based on limpieza de sangre. As exemplified by the rich quadroon from Guatemala discussed above, the presence of "bad black blood" in one's genealogy could not be erased or whitened, but extraordinary service could dispense a contaminated individual from the "defect" of being pardo or quadroon -never of being full black-. ${ }^{20}$

Another major Bourbon reform that required a skillful balance was the development of slavery to increase Spanish American colonies' production and exports. In February 1789 the monarchy deregulated the slave trade from Africa, but in order to prevent social disorder and greater autonomy among the Spanish and creole slaveholding elite, in May it issued "the royal instruction on the education, treatment and employment of slaves", better known as the Código Negro (black code). ${ }^{21}$ Promulgated just six weeks before the storming of the Bastille in Paris and the beginning of the French Revolution, the Spanish Black Code compiled former legislation on masters' and slaves' relations and aimed at reconciling Christian and human principles with Spain's will to expand slavery. The long list of slaveowners' duties included the provision of religious education and services; adequate food and clothing comparable to what is "commonly given to free day laborers"; and medical care, for example. In addition, the Código Negro stipulated that the principal occupation of slaves be agriculture, not domestic service, and that owners could make them work only from dawn to dusk, during which time two hours should be reserved daily for slaves to work for their own profit. In contrast, its list of slaves' duties was limited: "to obey and respect their masters and overseers, to fulfill the tasks and jobs that are assigned to them in conformity with their means, and to venerate them as heads of the family".

20 McALISTER, L.N. (1957): The "Fuero Militar" in New Spain, 1764-1800. University of Florida Press, Gainesville, pp. 1-15; SÁNCHEZ, J. (1994): "African Freemen and the Fuero Militar: A Historical Overview of Pardo and Moreno Militiamen in the Late Spanish Empire". Colonial Latin American Historical Review, vol. 3, pp. 165-184; VINSON III, B. (2001): Bearing Arms of His Majesty: The Free-Colored Militia in Colonial Mexico. Stanford University Press, Stanford; CHILDS, M.D. (2004): The 1812 Aponte Rebellion in Cuba and the Struggle Against Atlantic Slavery. The University of North Carolina Press, Chapel Hill, pp. 79-95.

21 "Real Instrucción sobre la educación, trato y ocupación de los esclavos" (May 31 st, 1789), in KONETZKE: Colección de documentos, pp. 643-652. 
Among the most controversial provisions of the Código Negro were those limiting slaves' working hours and those strictly defining the punishment owners and overseers could inflict on careless or disrespectful slaves, the maximum being 25 lashes "with a soft instrument that does not cause them serious contusion or spilling of blood". If masters believed that slaves deserved harsher punishment, they should turn them over to the justice system. Owners exceeding their right to punish would be prosecuted and incur "the penalty corresponding to the crime, as if the injured were free, and the slave would be confiscated to be sold to another master". In all court cases, the city's attorney would defend the slaves. In order to insure the good treatment of slaves, haciendas were subjected to the confidential supervision of the local priest and to three visits yearly by a special commissioner. ${ }^{22}$ Although the 1789 royal Código Negro was based on Roman law and the thirteenth-century code of Las Siete Partidas, in the context of the time, it did resemble a slaves' bill of rights. Moreover, some of its articles treated slaves as if they were free persons, in violation of owners' rights over their (human) property. Slaveholders in the rapidly developing plantation economies of Cuba and Venezuela immediately protested, claiming that if they obeyed its provisions, they would no longer be able to produce crops or goods for the benefit of the king. ${ }^{23}$

\section{The Impact of Saint-Domingue Revolution on Blood Purity, Race and SLAVERY}

In August 1791, the unexpected outbreak of the massive and deadly slave uprising in Saint Domingue abruptly ended the Spanish monarchy's plans to orderly develop slave plantation economies while keeping slaveholders under its control. The Council of the Indies issued a series of measures that pursued the contradictory goals of seizing the opportunity to fill the gap left by the destruction of Saint Domingue's sugar economy and of preventing any insurrection by libres de color and slaves similar to those unsettling the French colonies. The general belief was that, if protected from "contamination" by the corrupt ideas of liberty and equality promoted by the French Revolution, the Spanish dominions could develop peacefully and

22 "Real Instrucción sobre la educación, trato y ocupación de los esclavos" (May 31 st, 1789), in KONETZKE: Colección de documentos, pp. 643-652.

23 "Consulta del Consejo de las Indias sobre el reglamento expedido en 31 de mayo de 1789 para la mejor educación, buen trato y ocupación de los negros esclavos de América" (March 17th, 1794), in KONETZKE: Colección de documentos, pp. 726-732. 
become profitable. After a brief decline, the slave trade resumed, but Spain only authorized the direct imports of "uncontaminated" African slaves-ignoring the key role played by Kongos in Saint Domingue. ${ }^{24}$ Then, just after the French Convention abolished slavery in 1794, the Council of the Indies resolved to suspend the Código Negro and to give a freer hand to masters to exploit their slaves. But for fear that such a decision could prompt rumors and unrest among the latter, no decree was promulgated, and the Council recommended complete discretion in Spain's dominions. ${ }^{25}$

The role of free blacks and mulattos in Saint Domingue's revolution since 1790 also preoccupied white elites and royal authorities in Spanish America. Particularly worrying for them was the successful mobilization of French colonies' libres de couleur in favor of their full citizenship and equality with whites, which they gained in 1792. To prevent their emulation, the Council of the Indies and Spanish American authorities continued to affirm the absolute rule of limpieza de sangre, only tempered by the "dispense" of the status of pardo, cuarterón or quinterón (born of a cuarterón and a white) to exceptional or very wealthy individuals. In the colonies, the royal governors did their best to implement Madrid's decisions without alienating free people of color or white elites, as illustrated by the following examples. In early 1793, the Council of the Indies reiterated the exclusion of those who were not of legitimate birth and clean of "any stain and race of Moors, Jews and blacks" from all honorable charges or access to higher education. ${ }^{26}$ But with the recent reclassification of previously dishonorable manual skills as sciences, some exceptions had to be conceded, notably for the pardo medical doctors who attended courses of anatomy. ${ }^{27}$ When the Council imposed

24 THORNTON, J.K. (1993): "I Am the Subject of the King of Congo': African Political Ideology and the Haitian Revolution". Journal of World History, vol. 4:2, pp. 207-209.

25 GEGGUS, D.P. (1997): "Slavery, War, and Revolution in the Greater Caribbean, 1789-1815". In GASPAR, D.B. \& GEGGUS, D.P. (eds.): A Turbulent Time: The French Revolution and the Greater Caribbean. Indiana UP, Bloomington, p. 11; and CHILDS: The 1812 Aponte Rebellion, p. 39.

26 "Constituciones del colegio real de San Carlos en la ciudad de Buenos Aires" (January 14th, 1793), in KONETZKE: Colección de documentos, p. 711.

27 "Real Cédula que los pardos que ejerzan la medicina con real aprobación, puedan concurrir a la enseñanza de anatomía" (June 21 st, 1793), in KONETZKE: Colección de documentos, p. 719. 
new regulations to strengthen the racial line in the militia, several governors neglected to apply what they viewed as unnecessary humiliations that could alienate the loyalty of pardo and moreno militiamen. ${ }^{28}$

However, Spanish American elite whites worried that the 1792 French revolutionary decree of racial equality would prompt similar demands among the libres de color around them and submitted them to increased scrutiny. They dreaded any change that could destroy the racial paradigm on which colonial society was founded by opening a way out of the "stain of slavery". Nevertheless, in 1795, in an attempt to improve revenue collection, Madrid issued a price list of gracias al sacar (legitimations of status change sold by the Crown) that included certificates of legitimate birth, residency, but also dispenses of the status of pardo and quinterón (curiously, not cuarterón). ${ }^{29}$ These were quite likely what Tannenbaum called "purchas[ing] 'whiteness' for a specific price" (93). However, some whites immediately protested, despite the fact that these gracias only dispensed buyers and beneficiaries from their original calidad (quality), without explicitly granting them the status of white. White creoles, notably in Venezuela and Cuba, claimed that these dispenses would bring about "scandalous and subversive movements" and possibly a revolution led by the pardo militiamen. A growing number of whites complained that if many pardos applied for gracias al sacar, "believing that [these gracias] make them equal to whites without any other difference than the accident of their color", they would feel qualified for all positions and marriages with legitimate whites. ${ }^{30}$ The Council of the Indies reacted with empathy and agreed that to preserve "the political order", it was necessary to hold "individuals of vicious castes in a notably inferior position to legitimate whites and mestizos". Indeed, it was so difficult and costly to buy a gracia al sacar for one's racial "defects" that only a total of 24 men out of the several hundred thousand living in the

28 "Nota reservada del secretario de guerra al virrey de Nueva Granada" (November 6th, 1797), Archivo General de Indias, Sevilla, Secretaria de Guerra 7073, exp. 39; KUETHE, A.J. (1978): Military Reform and Society in New Granada, 1773-1808. Florida UP, Gainesville, pp. 177-178.

29 For the complete price list, see "Real Cédula insertando el nuevo arancel de los servicios pecuniarios señalados a las gracias al sacar" (August 3rd, 1801), in KONETZKE: Colección de documentos, pp. 778-783.

30 "Informe del ayuntamiento de Caracas" (November 28th, 1796), in IZARD, M. (1979): EI miedo a la revolución: La lucha por la libertad en Venezuela (1777-1830). Tecnos, Madrid, pp. 129-130, n. 16.

31 TWINAM, A. (2015): Purchasing Whiteness: Pardos, Mulattos, and the Quest for Social Mobility in the Spanish Indies. Stanford University Press, Stanford. Following Tannenbaum's lead, 
Spanish American empire attempted to do so between 1795 and 1812and very few of them succeeded. ${ }^{31}$ In 1806, new regulations legalized all marriages between Indians or "pure mestizos" and whites or Spaniards, but made marriages between persons of African descent and whites of noble status and/or legitimate birth contingent on special licenses, thus further setting apart blacks and mulattos. ${ }^{32}$

An even more striking evidence of the Spanish monarchy's will to uphold limpieza de sangre as the major racial divide was its racialization of culture and politics. In 1806, the Council of the Indies turned down the proposition of a high religious dignitary in Guatemala to "equal [the free castas] to the common class of Spaniards" in order to open new opportunities to them and free them from their "vices and disorders". The Council ruled that it was not only "color" that separated people of African descent from whites, Indians, and mestizos, but the "stain of slavery" as well as their "corrupt customs, being most of them bastard, adulterous, and illegitimate". In addition, "because of their perverse character, their pride, and inclination to liberty, they have been and they are not fond of our government and nation". ${ }^{33}$ Similarly, in 1807 the Council refused to extend to its colonies an 1803 cédula real (royal decree) that encouraged industry in Spain by declaring certain trades, such as blacksmith, tailor, shoemaker, and carpenter, "honest and honorable" and not degrading to artisans and their families. It argued that, because in America most artisans were of mixed African ancestry, the cédula would prompt disorder and make the castas believe that they were free from their vicious and infamous roots. ${ }^{34}$ Such a ruling showed that even in legislation, Tannenbaum's assessment that "the taint of slavery proved neither very deep not indelible" in Spanish America needed some qualification.

Ann Twinam still inaccurately calls «buying whiteness» the attempt by rich, legitimate free men of color to buy gracias al sacar for the «defect» of being pardo, mulatto or quadroon, despite the fact that she acknowledges that the handful of petitioners who were granted these expensive gracias did not get the status of blanco, but could overcome exclusions based on blood impurity for themselves and their offspring.

32 "Consulta del consejo sobre la habilitación de pardos para empleos y matrimonios" (July 1806), in KONETZKE: Colección de documentos, p. 826; MARTINEZ-ALIER: Marriage, Class and Colour, pp. 12-13

33 "Consulta del consejo sobre la habilitación de pardos para empleos y matrimonios" (July 1806), in KONETZKE: Colección de documentos, pp. 821-829.

34 "Dictamen del fiscal en el Consejo de las Indias sobre declarar en Américas que las artes y oficios mecánicos son nobles" (January 24th, 1807), in KONETZKE: Colección de documentos, pp. 832-834. 
Yet to block all hopes of social improvement for people of African descent could also generate revolt, as shown by the recent upheaval in the French Caribbean. And the Spanish monarchy knew that its American defense system relied heavily on black and mulatto militiamen. Thus, in 1806 the Council of the Indies also agreed to examine a few requests for gracias al sacar by men of mixed African ancestry with unique and extraordinary merits and services to the king, in view of dispensing them from their "quality of pardo". It also concluded that blacks and mulattos who could rigorously document four generations of legitimate birth and freedom qualified for any trade or office open to commoners in Spain. ${ }^{35}$ By singling out for royal privileges a small number of individuals of African ancestry who could prove exceptional merits and/or legitimate birth, particularly officers in the pardo or moreno militia, the Crown gave limited hopes to the upper strata of the growing urban free population of color while proving its unalienable attachment to the racial paradigm of the colonial society embodied by honorable whites of pure blood.

As for the development of slavery, the deregulation of the slave trade benefited principally Cuba, and to a lesser extent Puerto Rico, Venezuela and Río de la Plata. Of these, only Cuba became a slave society increasingly segregating its free population of color. Between the 1780s and the 1840s, the island transformed itself into Spain's most faithful and wealthiest colony, thanks to the forced labor of an increasing number of enslaved Africans and their descendants in sugar, coffee and tobacco production. After the outbreak of the Saint Domingue revolution, Cuba's creole planters were eager to seize the vacuum left by the destruction of the Caribbean's most profitable slave economy. Under the leadership of white Cuban economist Francisco de Arango y Parreño, they pressed Spain to continue the policy of African slaves' imports and to abrogate the Código Negro. Already in 1793 Arango designed the best means to develop agriculture in Cuba without falling into the same deadly trap as Saint Domingue. Abundant and cheap "instruments and blacks" as well as modern techniques needed to be imported to the island, he said, but "its development will be vain if we don't take measures against seditious movements by blacks and mulattos". According to him, la gente de color (people of color) included the enslaved and the free (whom he often called libertos [freedmen, despite the fact that many were freeborn]), who shared a common opposition to whites: "Some will say that the difference between being free or slave will separate their

35 "Consulta del consejo sobre la habilitación de pardos", in KONETZKE: Colección de documentos, pp. 826-828. 
interests and represent for us a respectable barrier. But all are blacks; they have more or less the same complaints and reason to live discontented with us". As Cuban whites' welfare rested on "the subordination and patience of a swarm of barbarous men", Arango continued, several measures were necessary to prevent "insurrection", such as the dissolution of the black and mulatto militias and their replacement with white battalions; a strict control of all veteran militiamen of color, particularly those living in the countryside; and the development of white communities in rural Cuba. ${ }^{36}$ Above all, in order to avoid a repetition of the "fatal event" in neighboring Saint Domingue, slaves were to be imported "with the census figures in hand, so that the number of blacks may not only be prevented from exceeding that of the whites, but that it may not be permitted to equal that number" ${ }^{37}$ Many of Arango's ideas were implemented-with the exception of his demographic rule and the dissolution of the militias of color. The flow to Cuba of African captives never stopped, complemented by slaves brought in by colons and free people of color escaping from Saint Domingue; and new regulations increasingly discriminated against the libres de color. Although the Napoleonic occupation of Spain in 1807 and the beginning of the independence movement in Spanish continental America affected the regularity of African slave imports, it also brought loyalist Spanish and creole refugees with their slaves to Cuba. ${ }^{38}$

\section{Citizenship in the 1812 Spanish Constitution and beyond}

Indeed, when Napoleon invaded Spain and forced King Ferdinand VII to abdicate, he abruptly put an end to the Bourbon reforms. Moreover, by symbolically beheading the Spanish monarchy, the French occupation of Spain launched the process of independence in Spanish continental America. Representatives from the provinces of the worldwide Spanish kingdom managed to meet in Cadiz and to debate how to govern while the king was in captivity; but the first constitution it adopted in 1812, despite many democratic advances, broadened the differences between Spaniards and Americans, and in America itself, between peninsulares and white creoles.

36 ARANGO, F. (2005 [1792]): "Discurso sobre la agricultura de La Habana y medios para fomentarla", in ARANGO, F.: Obras, Imagen Contemporánea, Havana, vol. I, pp. 144-198.

37 Cited in PAQUETTE, R.L. (1988): Sugar is Made with Blood: The Conspiracy of La Escalera and the Conflict between Empires over Slavery in Cuba. Wesleyan UP, Middletown, p. 84. In Saint Domingue, slaves represented $88 \%$ of the population, and together with free people of color, $93 \%$ of the population in 1789 .

38 CHILDS: The 1812 Aponte Rebellion, pp. 38-40; HELG: Liberty and Equality, p. 153. 
The 1812 Constitution established a constitutional monarchy. It confirmed the legitimacy of Spain's king, but limited his absolute power by establishing a government through ministers subjected to parliamentary control and the principle universal male suffrage. It reduced the Church and nobility's influence by guaranteeing the freedom of the press and by supporting tax reforms and an end to the feudal system.

Yet, the delegates from America were only 37 out of 303, when the overseas provinces had a combined population of 15 to 16 million, and continental Spain, about 10 to 11 million. Moreover, the Spanish American delegates were divided about such issues as slavery and blood purity. Despite a Mexican proposal of gradual emancipation (as in the U.S. North), the delegates decided, principally under Cuban insistence, to keep slavery intact in Spain and in America. Regarding the exclusions discriminating against libres de color, they also did not challenge them, in part because of some Spanish Americans' reticence, but, above all, because the Spanish Peninsula's delegates feared that by lifting them, the American provinces with an important population of free people of African descent would claim higher representation in the Cortes (parliament). ${ }^{39}$ As a result, the 1812 constitution recognized all free or freed persons born in the Spanish empire as españoles. However, it stipulated that only those whose genealogy demonstrated solely European and/or Indian American ancestry deserved to be "citizens". This represented a ground-breaking inclusion of all Indians and mestizos in the citizenry with voting rights, but simultaneously it confirmed the ongoing exclusion of the libres de color from representation. As Article 22 explained:

"For Spaniards with any proof or reputation of African origin in their genealogy, the door of virtue and merits will be open for them to be citizens: as a consequence, the Cortes will grant a certificate of citizenship to those who provide qualified services to the Fatherland or to those who distinguish themselves for their talent, application and behavior, as long as they are the legitimate children of parents born free from free parents, are themselves married to free women, resi-

39 O'PHELAN GODOY, S. (2012): "Los diputados peruanos en las Cortes de Cádiz y el debate sobre el tributo, la mita y la ciudadanía indígena". Revista de Historia Iberoamericana, vol. 5:1, pp. 94-1 10; SARTORIUS, D. (2014): Ever Faithful: Race, Loyalty, and the Ends of Empire in Spanish Cuba. Duke UP, Durham, pp. 22-31. 
dents in the Spanish dominions, and exercise some useful profession, office or industry with their own capital". ${ }^{40}$

To make sure that the material effects of old racial exclusions would continue, the Constitution stipulated that for all honors and public employment, including at the municipal level, it was necessary to be a Spanish citizen. Although a few whites of lower class probably gained new opportunities from the 1812 Constitution, the pool of men of African ancestry in condition to apply to citizenship was too tiny to represent any challenge to the rule of limpieza de sangre. The Constitution, thus, guaranteed their exclusion from power and politics.

This enduring exclusion contributed to seal the independence of continental Spanish America. Again, demographics mattered. Everywhere whites were a minority; slaves were concentrated in the cities (mostly as female domestics), the plantations and the mines. In every city, even Lima or Buenos Aires, free people of mixed African descent were more numerous than whites, and in Venezuela, Northern and Southern Colombia, for example, they were the majority of the rural population. For the white creole elite already envisioning independence, to exclude them from citizenship was not only non sense, but also dangerous. In contrast to offer them equal citizenship was the best means to attract those serving in the Spanish royal militias and to multiply manifold the size of the patriot armies. In fact, since 1810 no decree or laws promulgated by the autonomous (and later) proindependence juntas and governments made references to limpieza de sangre or mentioned libres de color as a category. Although white creole elites debated whether free blacks and mulattos should have the right to vote in elections, when they set limits to active citizenship, they used education and property requirements, not race to do so. ${ }^{41}$

After Ferdinand VII returned to the throne in 1814, he abrogated the 1812 Constitution and sent troops to his American colonies. His attempted Reconquista resulted in additional years of war, but it could not stop the independence process. In the 1820s, all Spanish continental colonies, from Mexico to Rio de la Plata and Chile, became republics, and their constitu-

40 "Constitución política de la Monarquía española de 1812", en DE ESTEBAN, J. (ed.) (1988): Las Constituciones de España. Taurus, Madrid, pp. 45-96. Note that on 15 May 1791, the French National Assembly had conceded full equality and citizenship to the same narrow group of selected libres de couleur, before granting both to all of them without discrimination on 4 April 1792.

41 HELG: Liberty and Equality, pp. 137-138. 
tions made no specific mention of the free population of African descent. All free individuals were legally equal, as rightly highlighted by Tannenbaum, but no policy aimed at correcting centuries of exclusion based on blood impurity, and thus the colonial racial hierarchies remained despite the departure of the Spanish loyalists.

Toward slavery, the newly independent republics took a much more cautious path, as many patriots from the white elite had slaves in their homes, their plantations or their mines. Slavery was a matter of contradictory individual rights-liberty and property. During the wars of independence, leaders, such as Simón Bolivar and José de San Martín, always short of able bodied men, recruited male slaves in their armies, with the promise of emancipation after the war. But after independence in the 1820s, only Chile, Central America and Mexico put an end to slavery, which had been displaced by other forms of labor in all sectors. Elsewhere in the Southern continent, only gradual abolition was approved: end of slave imports, free womb, emancipation of the elderly, and manumission funds to buy the freedom of a few deserving slaves. Theoretically, slavery could last another sixty years. Still, it crumbled as a result of the upheaval of the wars, the end of the slave trade, natural death, and slaves' self-purchase and flight. Yet, it was not fully abolished before the 1850s, that is, after the U.S. North, the British Caribbean, and the French Caribbean in 1848 had emancipated all their slaves.

Cuba and Puerto Rico remained faithful to the Spanish monarchy until 1898. In Cuba's case, both the opportunity to replace Saint Domingue as the major sugar producer and the fear of a black revolution along Haitian lines prevented the white creole elite from seeking independence. After 1814, the Spanish king granted Cuba with absolute free trade and rewarded its planters' loyalty with 36 titles of nobility. Cuba continued to rely on slavery and to yearly import thousands of slaves from Africa until the 1860s. ${ }^{42}$ Simultaneously, libres de color were further racialized, banned from the militias, and restricted in their freedoms. Yet, their numbers rose as a result of natural growth and self-purchase.

42 Between 1791 and 1866, the total number of Africans deported to Cuba reached 752,000and additional slaves were imported from the Caribbean and continental America. Out of these, 620,000 were illegally imported after 1817, when Spain signed with Great Britain a first treaty prohibiting the slave trade. VOYAGES Database (2010): Voyages: The Trans-Atlantic Slave Trade Database, http://www.slavevoyages.org (accessed May 25th, 2012). 
Change only came in the late 1860s (i.e. after the abolition of slavery in the U.S. South), first in Spain, then in Puerto Rico in the subsequent decade, and finally in Cuba in the 1880s. Between 1865 and 1870, in peninsular Spain certificates of blood purity ceased to be requested for admission to the army, the clergy, private and public colleges and universities, and public administration. In 1876, a new Spanish Constitution made no mention of race and of the African origin in any of its articles, and thus lifted the exclusion of Afro-Puerto Ricans and Afro-Cubans from Spanish citizenship. In 1873, slavery was abolished in Puerto Rico, and only in 1886 in Cuba, where simultaneously proofs of limpieza de sangre slowly began to vanish from applications to secondary and higher education and to church, military, or public positions. ${ }^{43}$

Yet, the 1877 official census of Cuba exemplified the continuing racial dichotomy of Cuban society. Its tables divided the population into four columns: españoles (presumably whites), extranjeros (foreigners), asiáticos (Chinese indentured workers), and on the far right, de color, gathering all people of full or mixed African descent under a unique category, without distinction between slaves and libres. Moreover, the new category of españoles registered white peninsulares and creoles against the tacitly non-Spanish de color in a remarkable illustration of the enduring exclusion of people of African descent from the citizenry set by the short-lived 1812 Spanish constitution. The census of 1887, just one year after the abolition of slavery in Cuba, eventually included Afro-Cubans in the category of españoles, separated from extranjeros, thus granting them citizenship and equal rights, but simultaneously it had new columns classifying La población de hecho con distinción de color (sic) that separated blancos from de color according to gender and educational level. ${ }^{44}$

No doubt, in 1946 Tannenbaum's Slave and Citizen stimulated the debate on slavery and race relations in America as a whole. It pointed to important differences between Anglo-Saxon and Latin America in their slave legislation and the role of the church. It stressed the inclusive version of Christianity promoted by the Catholic Church and the protection that Latin

43 INSTITUTO Internacional de Genealogía y Heráldica (1979): Estudios a la Convención Del Instituto Internacional de Genealogía y Heráldica con Motivo de Su XXV Aniversario (19531978). CSIC, Madrid, p. 325; "Constitución de la monarquía española de 1876", en DE ESTEBAN, J. (ed.) (1988): Las Constituciones de España. Taurus, Madrid, pp. 177-190.

44 INSTITUTO Geográfico y Estadístico (1883-1884): Censo de la población de España: según el empadronamiento hecho en 31 de diciembre de 1877, Madrid, vol. 1, pp. 692-693; INSTITUTO Geográfico y Estadístico (1891): Censo de la población de España según el empadronamiento hecho en 31 de diciembre de 1887, Madrid, pp. 770-771. 
American slaves could find in a legislation that also favored their pursuit of freedom through self-purchase. On the contrary, in the U.S. South slaves were denied full humanity and excluded from the civil community; they faced harsh laws that offered them no legal path to freedom; and once emancipated, they met racial violence, segregation, and black codes. Slave and Citizen also integrated the history of the American continent, and its positive views on Latin America encouraged historical research on race and slavery in Brazil and Spanish America.

Yet, as this article demonstrates, in colonial Spanish America, for African or Afro-descended individuals and communities, transition from slavery to freedom did not mean equal conditions before the law with whites. First, slavery was the primary condition of Spanish America's people of African descent, who were the only ones who could be legally enslaved. Second, by law slaves could purchase their freedom, but once free, the stain of slavery, the mancha de la esclavitud, still "contaminated" their "blood" and continued to "infect" the blood of their children and grandchildren, whether they were of mixed or unmixed African ancestry. Although their baptism by the Catholic Church should have washed their sins and regenerated them as children of God, they were racially stigmatized and collectively labeled impure, whether they were slaves, freedmen and freeborn persons. Third, the appellation of libres de color identified them separately from the free persons of Spanish and Indian descent with no African ancestry in their lineages; they were collectively excluded from the limpieza de sangre and singled out by many racially discriminating laws and rulings. As a result, manumitted and freeborn people of full or mixed African origin were legally denied access to most civil, military, and church positions, to higher education, to non-manual professions, to all kinds of grants and honors on the basis of their race; their marriages to whites and Indians were subjected to special authorizations; and they were deprived from the Spanish citizenship. And fourth, freedmen and freedwomen and their offspring could not "purchase whiteness", despite the claim of Tannenbaum and some historians up to the present. Only those of partial African descent -not full blacks- could apply to "dispenses for their defects", and such applications, reserved to wealthy individuals of exceptional merits, required such a costly, complex, and long investment that only 24 individuals undertook it between 1795 and 1812 -and most of them failed or did not receive a decision-. Indeed, a far more relevant question remains why only 24 free mulattos, pardos, zambos or quadroons out of the several hundred thousand free persons of African descent living in colonial Spanish America at that time thought that it was worth applying for a gracia al sacar. 
At any rate, in the still Spanish islands of Puerto Rico and Cuba, the statutes of blood purity and the racial discriminations against people of African descent remained in force until the abolition of slavery, in 1873 and 1886, respectively. In contrast, in continental Spanish America, they were lifted during the independence process and in all the constitutions promulgated in the 1820s, despite the fact that most new republics did not abolish slavery. There, in an extraordinary move, the new republican leaders (many born into the colonial white creole elite) erased the mancha de la esclavitud and all its discriminatory effects, including the exclusion from citizenship. Yet, the Spanish colonial exclusion of men of partial or full African ancestry from higher education continued to weigh on the formation of the new nations' elite, as it now kept them out of government positions not on the basis of their race, but of their lack of formal education. 